\title{
Uji Usabilitas Sistem Jual Beli Produk Pertanian
}

\section{(Usability Testing for Agriculture Product Trading System)}

\author{
Joko Purwadi ${ }^{1}$, Halim Budi Santoso ${ }^{2}$, Argo Wibowo ${ }^{3}$, Novia Indrayono Rante ${ }^{4}$, Rosa Delima ${ }^{* 5}$ \\ ${ }_{1,4,5}$ Program Studi Informatika, Fakultas Teknologi Informasi, Universitas Kristen Duta Wacana \\ ${ }^{2,3}$ Program Studi Sistem Informasi, Fakultas Teknologi Informasi, Universitas Kristen Duta Wacana \\ 1jokop@staff.ukdw.ac.id, 2hbudiestaff.ukdw.ac.id, 3argoestaff.ukdw.ac.id, \\ ${ }^{4}$ novia.indrayono@ti.ukdw.ac.id, ${ }^{* 5}$ rosadelimalstaff.ukdw.ac.id
}

\begin{abstract}
Abstrak - Sebuah proyek pengembangan perangkat lunak melalui banyak tahapan dimulai dari pendefinisian kebutuhan sampai dengan penerapan. Sebelum proses penerapan sistem, tim pengembang akan melakukan uji kebergunaan (usabilitas) terhadap aplikasi. Tahap ini sangat penting untuk menjamin agar proses implementasi dapat dilakukan dengan baik dengan minimalisasi permasalahan. Tahapan dalam penelitian meliputi studi pendahuluan, penentuan responden, pengembangan tools uji, pembuatan scenario tugas, pelaksanaan tes, analisis data, dan perumusan hasil. Uji dilakukan terhadap tiga puluh lima responden, tiga puluh responden merupakan pembeli dan penjual sementara lima responden sebagai admin pembeli dan penjual pada sistem. Responden yang terlibat dalam pengujian merupakan pembeli dan penjualan produk pertanian dari daerah Bantul dan Salatiga. Pengujian dilakukan terhadap efisiensi dan efektifitas sistem. Efisiensi diukur melalui Time on Task Rate dan Number of Clicks Rate, sementara efektifitas diukur melalui Task Success Rate dan Error Rate. Berdasarkan hasil pengujian diketahui bahwa sistem cukup efisien dan memiliki efektifitas yang baik.
\end{abstract}

\section{Kata-kata kunci: E-Commerce Pertanian, Usability Testing, Efisiensi Sistem, Efektifitas Sistem}

Abstract - A software is developed through some stages, starting from requirement definition to implementation. Before system implementation, developers conduct an application usability test. This test is essential to guarantee that the implementation process can run well and minimize the problems later. There are some steps to conduct a usability test: a preliminary study, defining respondent, test tools development, scenario task determination, test execution, data analysis, and discussion. Thirty respondents were involved in the usability tests, including sellers and buyers, while five respondents are system administrators. Respondents involved in the study were buyers and sellers of agricultural products from the Bantul and Salatiga regions. Usability tests are done to measure system efficiency and effectiveness. Efficiency is measured through Time on Task Rate and Number of Clicks Rate. Task Success Rate and
Error Rate measure effectiveness. Based on the test, the system can run efficiently and effectively.

Keywords: Agriculture E-Commerce, Usability Testing, System Efficiency, System Effectivity

\section{PENDAHULUAN}

Pertanian merupakan kegiatan ekonomi sebagian besar penduduk Indonesia. Teknologi informasi dapat memberikan peran yang besar untuk memperluas pasar penjualan produk pertanian. Beberapa aplikasi penjualan produk pertanian yang telah dikembangkan di negara Asia dan Afrika, yaitu e-Choupal (India), Agricultural Market Information System (Bangladesh), dan Infotrade (Uganda) [1]. Saat ini telah dikembangkan beberapa sistem informasi/ aplikasi di bidang pertanian di Indonesia yaitu [2] [3] [4]. Salah satu aplikasi pertanian yang telah dikembangkan adalah Sistem Informasi Penjualan dan Pembelian (E-Commerce) Produk Pertanian [4].

Sistem Penjualan dan Pembelian Produk Pertanian merupakan sistem untuk mendukung perluasan informasi pasar bagi petani dan pelaku usaha bidang pertanian di daerah pedesaan. Sistem telah selesai dikembangkan pada tahun 2018 dan untuk melakukan hilirisasi perlu dilakukan pengujian terhadap kebergunaan (Usability). Pengujian tersebut bertujuan mengetahui tingkat kepuasan pengguna, efisiensi dan efektifitas penggunaan aplikasi. Uji usabilitas terhadap sistem meliputi variabel task success, efficiency, error, dan time on task.

Menurut ISO 9241:11 [5], usabilitas merupakan ukuran seberapa baik/tepat suatu produk dapat digunakan oleh pengguna untuk mencapai target efektifitas, efisiensi dan kepuasan pengguna dalam konteks pengguna tertentu. Konteks penggunaan meliputi pengguna, tugas, piranti (keras, lunak dan material pendukung). Berdasarkan definisi tersebut, 
usabilitas diukur berdasarkan komponen sebagai berikut [6]:

a. Kemudahan (learnability), kecepatan pengguna mahir menggunakan sistem, kemudahan pengguna menjalankan suatu fungsi, serta apa yang pengguna inginkan dan pengguna mendapatkan.

b. Efisiensi (efficiency), sumber daya yang dikeluarkan untuk mencapai ketepatan dan kelengkapan tujuan.

c. Mudah diingat (memorability), bagaimana kemampuan pengguna mempertahankan pengetahuan setelah jangka waktu tertentu.

d. Kesalahan dan Keamanan (errors), berapa banyak dan kesalahan apa yang dilakukan pengguna, mencakup ketidaksesuaian yang dipikirkan pengguna dengan yang sebenarnya disajikan sistem.

e. Kepuasan (satisfaction), kebebasan dari ketidaknyamanan dan sikap positif terhadap penggunaan produk atau nilai subjektifitas pengguna berkenaan dengan penggunaan sistem.

Komponen - komponen dari uji usabilitas tersebut dapat diukur dengan beberapa cara pengukuran [7] [8] yaitu task success untuk mengukur tingkat efektifitas pengguna menyelesaikan tugas yang diberikan peneliti. Data disajikan dalam bentul tabel dengan skala 0 (task gagal) dan 1 (task sukses). Komponen kedua adalah time-on-task untuk mengukur banyaknya waktu yang dibutuhkan pengguna menyelesaikan tugas, perhitungan waktu (dengan stopwatch), kemudian disajikan di tabel untuk mendata waktu yang diperlukan pengguna untuk menyelesaikan satu task dan menyajikan rata-rata, serta median waktu yang dibutuhkan pengguna untuk mencapai tujuan menggunakan sistem. Komponen ketiga adalah error untuk mengetahui kesalahan saat melakukan pengujian sistem dan dicatat pada tabel yang berisi tugas dimana pengguna melakukan kesalahan dan komponen terakhir efficiency melalui number of click untuk mengetahui seberapa banyak usaha yang dilakukan pengguna dalam menyelesaikan sebuah task. Jumlah click dipergunakan untuk menilai aspek efficiency.

Uji usabilitas telah dilakukan oleh beberapa peneliti, diantaranya untuk melakukan pengujian terhadap website alumni STIKOM Bali [9], website pemerintah desa jagalempeni [10], dan website Universitas Brawijaya [11]. Berdasarkan proses uji usabilitas yang dilakukan dapat membantu peneliti dalam memahami kebutuhan pengguna akan kualitas informasi dan kualitas interaksi yang baik.

E-Commerce merupakan model bisnis yang sangat berkembang dan menjanjikan dengan memanfaatkan teknologi informasi dan komunikasi (TIK) [12]. Menurut TURBAN, et. al. (2012), E-Commerce disingkat EC adalah perdagangan yang mencakup proses penjualan, pembelian, transfer, dan pertukaran produk layanan atau informasi melalui jaringan komputer, termasuk internet. Industri perdagangan elektronik ini merupakan penerapan dari e-bisnis yang berkaitan dengan transaksi komersial dan mencakup beberapa operasional lainnya [13].

Perkembangan bisnis E-commerce di Indonesia memiliki potensi besar, "Kementerian Perdagangan Republik Indonesia memperkirakan transasksi jual beli barang melalui internet (E-commerce) dari Indonesia akan menembus angka US\$ 10,08 milliar. Rata-rata transaksi belanja online tersebut tumbuh $40 \%$ setiap tahun". Agus Tjandra selaku vice chairman \& foreign relation asosiasi e-commerce Indonesia (idEA) pada penandatanganan kerja sama e-commerce antara Federasi Teknologi Informasi Indonesia (FTII) dan Taipei Computer Association (TCA) di Jakarta menyatakan bahwa total nilai transaksi e-commerce Indonesia pada tahun 2013 mencapai US\$ 8 milliar atau sekitar Rp. 94 trilliun dan diprediksi terus meningkat hingga mencapai US\$ 24 milliar atau sekitar RP. 283 trilliun pada 2016. Jumlah orang yang berbelanja secara online di Tanah Air tercatat mencapai 4,6 juta orang selama 2013 dan diperkirakan meningkat menjadi 8,7 juta orang pada tahun 2016 [14].

E-commerce memberikan manfaat kemudahan bagi pengusaha dan konsumen/pengguna. Manfaat $e$ commerce antara lain meningkatkan pendapatan pengusaha, mengurangi biaya operasional perusahaan, menghemat waktu berbelanja bagi konsumen, dan memiliki tingkat kenyamanan dalam berbelanja [15].

Sistem Penjualan Dan Pembelian Produk Pertanian dinamai DODOLANTANI. DODOLANTANI merupakan Sistem Penjualan dan Pembelian Produk Pertanian, sistem ini dikembangkan untuk mendukung pembangunan ekonomi dan ekspansi pasar bagi para petani khususnya dan konsumen yang berada di daerah pedesaan [4].

E-commerce DODOLANTANI memiliki dua modul utama yaitu modul pembelian dan penjualan. Modul pembelian berfungsi mengatur proses pembelian produk untuk login pengguna (pembeli dan admin), terlihat pada Gambar 1a, pengguna wajib mendaftar sebagai pembeli terlebih dahulu. Tampilan setelah pembeli melakukan login adalah halaman produk (Gambar 1b). Halaman produk memberikan fasilitas pembeli untuk melihat, mencari, dan berdiskusi mengenai produk yang akan dibeli. Pembeli selanjutnya bisa melakukan transaksi pembelian dengan menekan tombol beli pada detail produk (Gambar 1c) dan akan tampil transaksi pembelian (Gambar 1d). Tahap selanjutnya, pembeli 
akan dihadapkan pada halaman shopping cart (Gambar 1e) dan pembeli dapat melakukan transaksi pembayaran. Berikutnya, pembeli melakukan upload bukti pembayaran, dilanjutkan dengan admin sistem melakukan verifikasi pembayaran tersebut. Verifikasi dilakukan melalui halaman validasi (Gambar 1f). Jika pembayaran tidak sesuai, maka admin sistem akan mengirimkan notifikasi terhadap pembeli pada halaman pembelian. Jika pembayaran sudah benar dan tervalidasi, maka proses berlanjut melakukan pengiriman barang melalui kurir yang ditetapkan [4].

E-commerce DODOLANTANI memiliki modul penjualan untuk mendukung pelaku bisnis atau penjual melakukan transaksi penjualan barang. Modul penjualan memiliki tampilan halaman penjual dan admin. Pengguna diwajibkan untuk mendaftar sebagai penjual terlebih dahulu. Tampilan halaman daftar produk, masukan detail penawaran produk, transaksi penjualan, diskusi produk, dan laporan penjualan dapat dilihat pada Gambar 2 [4].

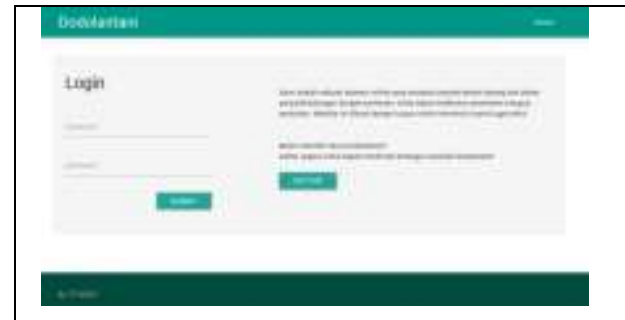

(a) Halaman login pengguna
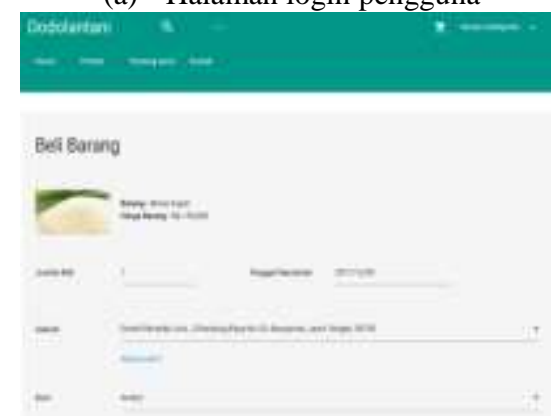

(d) Halaman pembelian

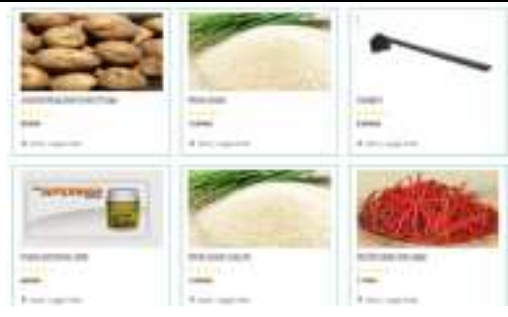

(b) Halaman produk

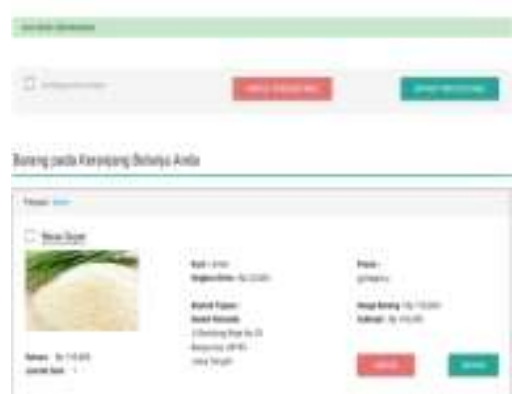

(e) Halaman daftar pembelian

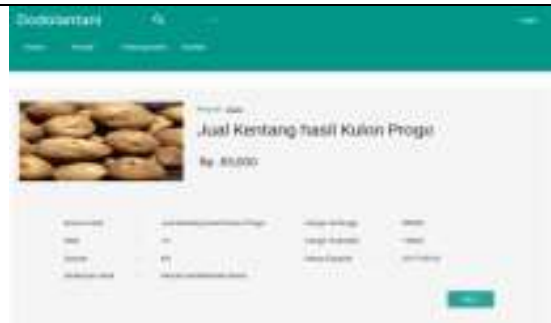

(c) Halaman detail produk

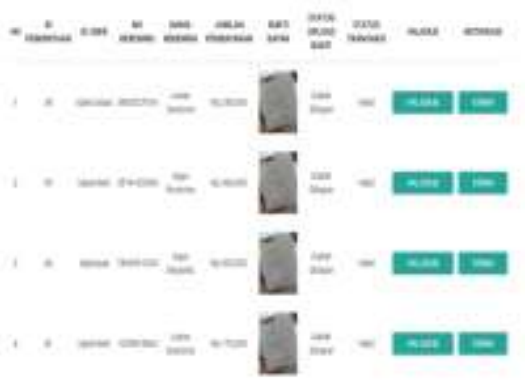

(f) Halaman validasi pembayaran

Gambar 1. Halaman pada modul pembelian

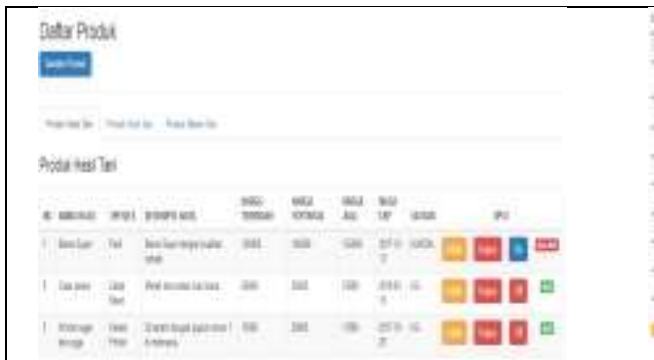

(a) Halaman daftar produk

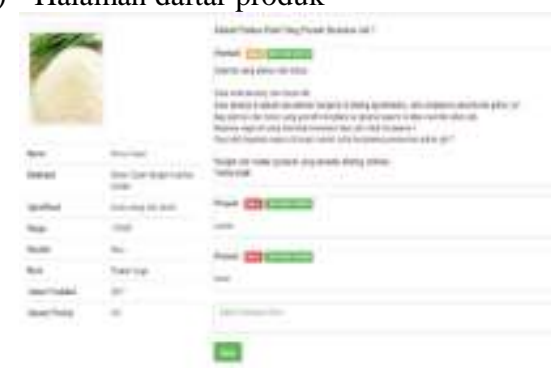

(d) Halaman diskusi produk

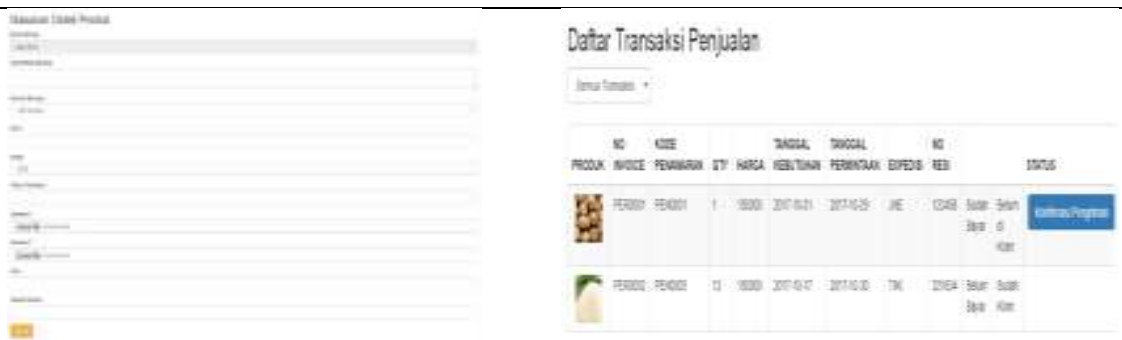

(b) Halaman detail produk

(c) Halaman daftar transaksi penjualan

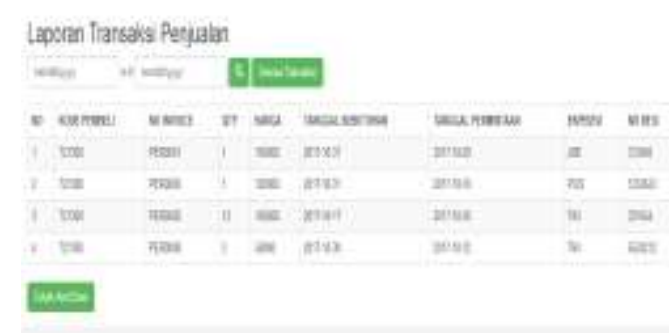

(e) Halaman laporan penjualan

Gambar 2. Halaman pada modul penjualan 


\section{METODE}

Penelitian menerapkan metode pengujian yang terdiri dari enam tahapan, yaitu studi pendahuluan, studi partisipan/responden, pengembangan tool uji, pelaksanaan, analisis data, dan rumusan hasil. Bagan tahapan penelitian dapat dilihat pada Gambar 3.

\section{A. Preliminary Study}

Preliminary study/Studi pendahuluan merupakan tahap membuat perencanaan, identifikasi kebutuhan, dan sumberdaya penelitian. Pelaksanaan uji usabilitas dilaksanakan pada bulan Mei - Juli 2019 di daerah Jawa Tengah, pengambilan data secara langsung ke stakeholder pertanian yang meliputi petani, penjual produk pertanian, dan kelompok tani.

Piranti pendukung uji usabilitas dengan perangkat komputer/laptop dan sistem e-commerce yang telah dikembangkan, alat uji usabilitas berupa kuesioner dan daftar tugas, serta tools pendukung pengambilan data. Sumberdaya yang terlibat dalam penelitian meliputi tim peneliti yang berjumlah 5 orang, dana pendukung penelitian, dan perangkat/alat untuk melakukan pengujian sistem.

\section{B. Participants Study}

Responden penelitian terdiri dari dua kelompok, kelompok pertama adalah responden pengguna akhir sebagai pembeli dan penjual. Kelompok kedua adalah responden sebagai admin pada sistem. Target keseluruhan banyak responden adalah minimal 30 responden, dengan kriteria untuk pembeli dan penjual minimal berusia 20 tahun, pendidikan minimal SMP, dan dapat mengoperasionalkan komputer/laptop.

\section{Develop Tools}

Tools pengujian usabilitas membutuhkan daftar tugas, kuesioner, dan tools pendukung pengambilan data. Daftar tugas dibuat berdasarkan skenario fitur sistem DODOLANTANI. Pengujian pengguna menggunakan kuesioner dan didukung google form sebagai tools untuk proses pengambilan data. Skenario tugas terbagi menjadi tiga pengguna pada sistem yaitu pembeli, penjual, dan admin pembeli. Daftar tugas menyesuaikan dengan jenis pengguna, Daftar Tugas dapat dilihat pada Tabel II.

\section{Conduct Testing}

Tes dilakukan dengan menggunakan skenario tugas. Uji skenario dilakukan dengan mendatangi responden dan uji usabilitas dilakukan untuk mendapatkan nilai task success, time on task, error, dan efficiency. Formula untuk setiap variabel uji dapat dilihat pada persamaan (1) sampai (4) [16]

$$
\text { Time on Task Rate }=\frac{\sum \text { Rerata Time on Task }}{\sum \text { Waktu benchmark }}
$$

Number of Clicks Rate

$$
\begin{array}{r}
=\frac{\sum \text { Rerata Number of Clicks }}{\sum \text { Minimal Click benchmark }} \\
\text { Task Success Rate }=\frac{\sum \text { Task Success }}{\sum \text { Task }} \\
\text { Error Rate }=\frac{\sum \text { Error }}{\sum \text { Maksimum Error }}
\end{array}
$$

\section{E. Data Analysis}

Analisis data meliputi analisis task succes, time on task, error, dan efficiency. Analisis task succes berdasarkan data keberhasilan responden dalam menyelesaikan tugas. Keberhasilan diukur melalui tingkat keefektifan responden dalam menyelesaikan setiap task yang diberikan. Menurut Sauro [8] tolak ukur jika tingkat persentase keberhasilan lebih besar dan atau sama dengan $78 \%$, maka task tersebut dinyatakan telah dapat diselesaikan dengan baik. Jika dibawah 78\%, maka task tersebut dinyatakan gagal diselesaikan dan menjadi indikator perlunya perbaikan pada bagian tersebut.

Analisis time on task mengacu pada waktu yang dibutuhkan responden dalam menyelesaikan setiap task yang diberikan. Peneliti melakukan pencatatan setiap partisipan dan setiap task yang dikerjakan. Data waktu dalam satuan detik dan disajikan dalam tabel, dan ada rataan waktu untuk setiap task. Task dengan rerata waktu lebih besar dari batas maksimal maka diketahui bahwa partisipan mengalami kesulitan dalam mengerjakan task. Peneliti dapat menentukan kesimpulan ada perbaikan pada task yang memiliki rataan waktu lebih besar dari batas waktu maksimal.

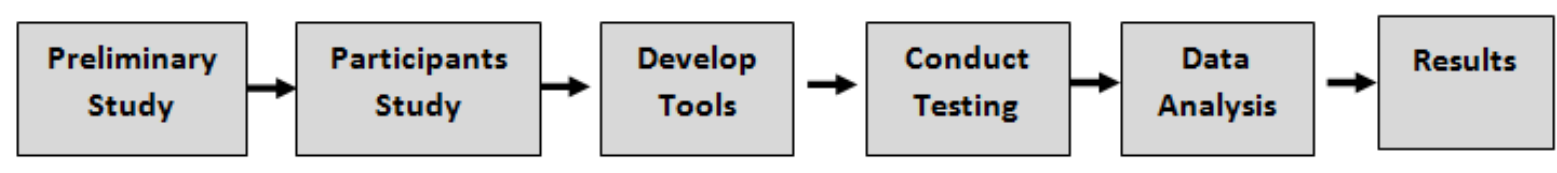

Gambar 3. Tahapan penelitian 
Analisis error diperoleh berdasarkan hasil penyelesaian task, apakah terdapat kesalahan yang dilakukan partisipan/user dalam menyelesaikan suatu task dan analisis efficiency diperoleh berdasarkan jumlah click yang dilakukan partisipan/responden dalam melakukan suatu task. Semakin minim jumlah click dalam menyelesaikan tugas, maka semakin efisien sistem yang telah dikembangkan.

Data hasil uji dipergunakan untuk mengolah data selanjutnya dengan menggunakan Combining Metrics Based on Percentages, yang merupakan salah satu teknik sederhana untuk menggabungkan nilai skala yang berbeda untuk mengkonversi setiap skor dalam persentase, dan selanjutnya diambil nilai rata-rata.

\section{F. Result}

Hasil uji usabilitas berupa nilai dan level usabilitas dari sistem. Hasil uji akan dijadikan dasar memberikan rekomendasi kepada pengembangan sistem. Rekomendasi dipergunakan untuk perbaikan pada Sistem Penjualan dan Pembelian Produk Pertanian.

\section{HASIL DAN PEMBAHASAN}

\section{A. Karakteristik Responden}

Responden pada penelitian ini berjumlah 35 orang, dengan distribusi jumlah sebanyak 30 responden merupakan pembeli sekaligus penjual dan lima orang responden merupakan user admin baik pembelian maupun penjualan. Responden berasal dari Bantul dan Salatiga. Karakteristik responden dapat dilihat pada Tabel I.

Berdasarkan data pada Tabel I diketahui bahwa sebagian besar usia responden antar 31 sampai 50 tahun yang mencapai $78 \%$. Berdasarkan jenis kelamin, responden penelitian cukup berimbang meskipun persentase wanita lebih banyak dari pria, namun perbedaan tidak terlalu signifikan. Berdasarkan tingkat pendidikan, persentase terbesar adalah pendidikan S1 yaitu sebesar $37 \%$.

\section{B. Pengambilan Data}

Pengujian dilakukan mulai Mei sampai Juli 2019, sebelum melakukan pengujian dilakukan wawancara singkat untuk menggali pengalaman responden dalam penggunaan laptop dan smartphone. Proses ini dilakukan untuk memastikan bahwa responden kualifikasi seperti yang disyaratkan. Jika responden memenuhi persyaratan selanjutnya tester memberikan penjelasan tujuan pengambilan data dan memberikan penjelasan singkat terkait sistem yang akan diujikan. Responden diminta untuk mengisi lembar persetujuan. Kemudian responden diberi waktu untuk mencoba menjalankan sistem secara mandiri. Jika waktu dinilai cukup maka selanjutnya dilakukan pengambilan data uji terhadap penyelesaian tugas sesuai scenario yang telah disusun. Setelah selesai proses berlanjut dengan pengisian kusioner SUS untuk mengetahui tingkat penerimaan pengguna. Diagram alir pengambilan data dapat dilihat pada Gambar 4.

\section{Penentuan Benchmark}

Penelitian ini melibatkan 30 pembeli, 30 penjual, 5 admin pembelian dan 5 admin penjual. Uji usabilitas ini dilakukan dengan cara meminta responden menyelesaikan tugas pada Tabel II. Analisis dilakukan terhadap 4 variabel usabilitas yaitu task success, time on task, error dan efficiency.

Sebelum dilakukan pengujian, terlebih dahulu ditentukan benchmark waktu pelaksanaan tugas sebagai standar waktu yang akan digunakan dalam uji usabilitas. Benchmark diperoleh melalui ujicoba pelaksanaan tugas yang dilakukan oleh pengembang sistem. Selain standar waktu, benchmark juga dilakukan untuk jumlah klik pada aplikasi untuk masing-masing tugas. Standar waktu dijadikan waktu maksimal untuk menilai keberhasilan penyelesaian tugas oleh responden. Daftar tugas, benchmark waktu dan jumlah klik yang digunakan pada uji usabilitas dapat dilihat pada Tabel II.

TABEL I

KARAKTERISTIK RESPONDEN

\begin{tabular}{llll}
\hline Variabel & Kelas & Jumlah & Persentase \\
\hline Usia & $20-30$ tahun & 9 & $26 \%$ \\
& $31-40$ tahun & 12 & $34 \%$ \\
& $41-50$ tahun & 12 & $34 \%$ \\
& $>50$ tahun & 2 & $6 \%$ \\
\hline Jenis & Pria & 16 & $46 \%$ \\
Kelamin & Wanita & 19 & $54 \%$ \\
\hline Tingkat & SMP & 5 & $14 \%$ \\
Pendidikan & SMA & 1 & $3 \%$ \\
& D3 & 4 & $11 \%$ \\
& S1 & 13 & $37 \%$ \\
& S2 & 1 & $3 \%$ \\
\hline
\end{tabular}

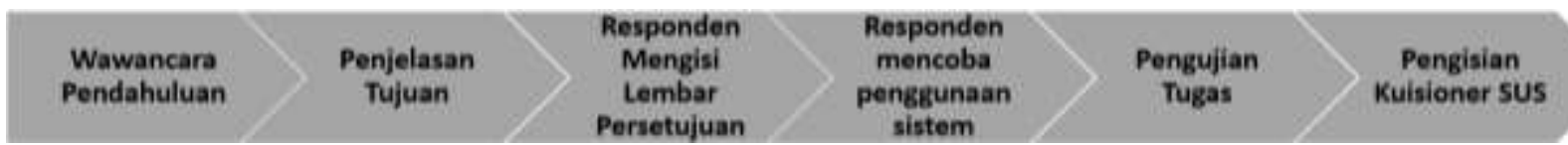

Gambar 4. Diagram alur proses uji usabilitas sistem. 
TABEL II

DAFTAR TUGAS, BENCHMARK WAKTU DAN JUMLAH KLIK

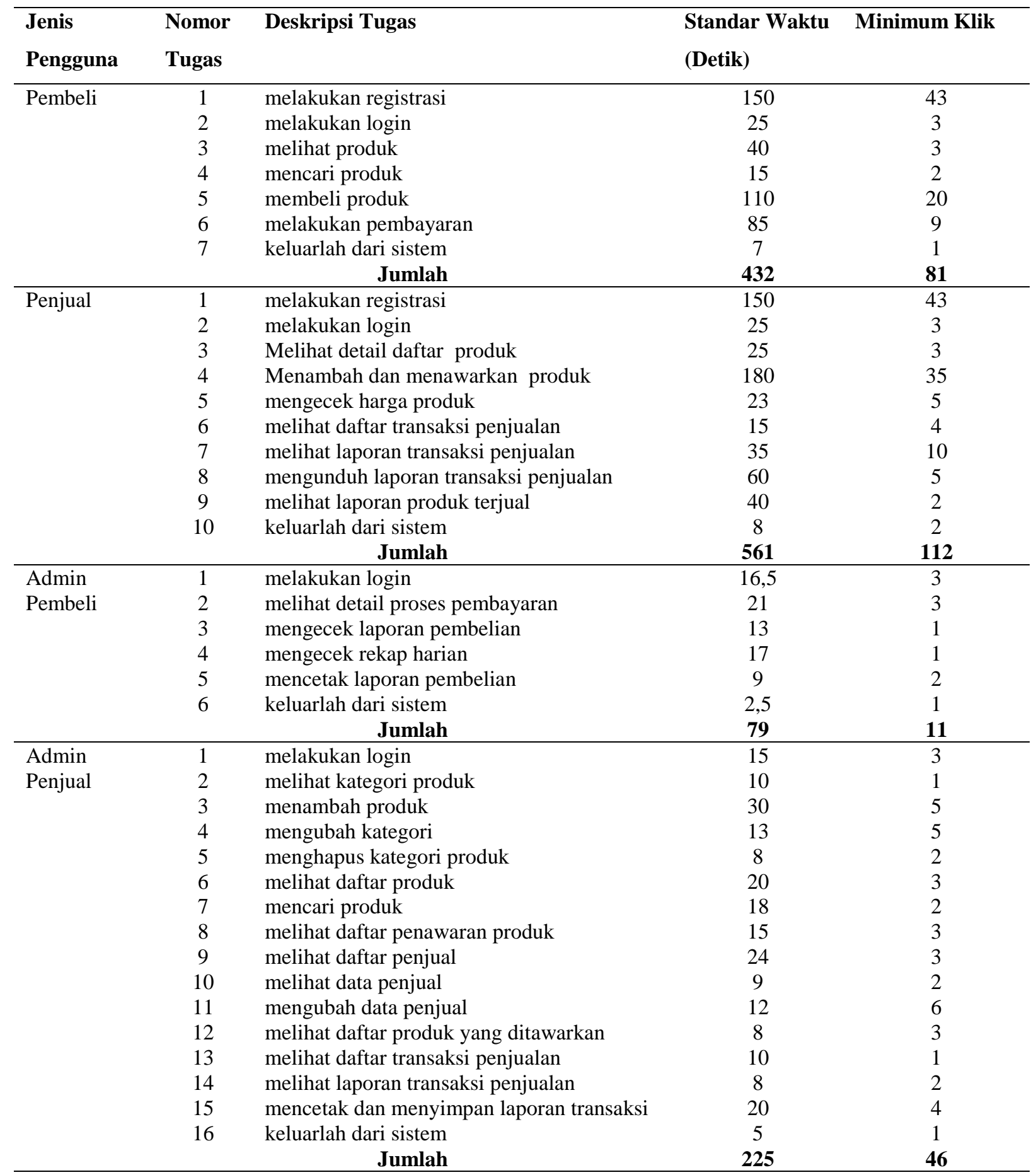

\section{Hasil Uji Usabilitas Pembeli}

Uji usabilitas dilakukan terhadap 30 orang pembeli dengan jumlah task sebanyak 7. Pengujian dilakukan untuk mengukur time on task, number of clicks, task success dan banyak error. Time on task dilakukan dengan mengukur lama waktu pengguna melakukan skenario tugas yang ditetapkan. Waktu diukur dalam satuan detik. Number of clicks dan task success masingmasing diukur berdasarkan banyaknya klik yang 
dilakukan pengguna saat menjalankan task dan jumlah task yang berhasil diselesaikan oleh pengguna. Sementara itu error dihitung berdasarkan banyaknya pengguna yang melakukan kesalahan saat menjalankan task. Hasil uji usabilitas pembeli dapat dilihat pada Tabel III.

Tabel III memberikan informasi bahwa total waktu yang dibutuhkan pengguna untuk menyelesaikan semua task adalah 784 detik dengan rata-rata waktu 112 detik. Jika dibandingkan dengan data benchmark time on task pada Table III diketahui bahwa time on task rate untuk pembeli adalah 1,81 yang berarti pengguna membutuhkan waktu 1,81 kali dari tim pengembang. Sementara itu untuk number of clicks diketahui bahwa rerata total klik yang dibutuhan pengguna adalah 132 klik atau sekitar 1,63 jika dibandingkan dengan jumlah minimum klik oleh tim pengembang yaitu sebesar 81 klik. Waktu dan banyak klik ini dinilai cukup baik meskipun berada diatas 1,5 benchmark namun masih dibawah 2 dari waktu dan jumlah klik minimal benchmark. Total tingkat keberhasilan pengguna adalah sebesar 177 task diselesaikan dari keseluruhan 210 task atau $84 \%$ task mampu diselesaikan pengguna. Banyak error yang dilakukan responden pembeli ada 102 error dari maksimum 210 kesalahan. Hal ini berarti tingkat error sebesar 0,46 yang berada dalam tingkat wajar.

\section{E. Hasil Uji Usabilitas Penjual}

Uji usabilitas penjual dilakukan dengan 30 responden dengan jumlah task sebanyak 10. Pengujian dilakukan dengan cara dan untuk variabel yang dama dengan pembeli, yaitu time on task, number of click, task success dan banyak error. Hasil uji usabilitas penjual dapat dilihat pada Tabel IV.

TABEL III

HASIL UJI USABILITAS PEMBELI

\begin{tabular}{ccc}
\hline Variabel & Total & Rerata \\
\hline Time on Task (detik) & 784 & 112 \\
Number of Clicks & 132 & - \\
Number of Task Success & 177 & 25,29 \\
Number of Error & 102 & 14,57 \\
\hline
\end{tabular}

TABEL IV

HASIL UJI USABILITAS PENJUAL

\begin{tabular}{ccc}
\hline Variabel & Total & Rerata \\
\hline Time on Task (detik) & 971 & 97,1 \\
Number of Clicks & 208 & - \\
Number of Task Success & 260 & 26 \\
Number of Error & 108 & 10,8 \\
\hline
\end{tabular}

Tabel IV memberikan informasi bahwa total waktu yang dibutuhkan pengguna untuk menyelesaikan semua task adalah 971 detik dengan rata-rata waktu 97,1 detik. Jika dibandingkan dengan data benchmark time on task pada Table III diketahui bahwa time on task rate untuk pembeli adalah 1,81 yang berarti pengguna membutuhkan waktu 1,73 kali dari tim pengembang. Sementara itu untuk number of clicks diketahui bahwa rerata total klik yang dibutuhan pengguna adalah 208 klik atau sekitar 1,86 jika dibandingkan dengan jumlah minimum klik oleh tim pengembang yaitu sebesar 112 klik. Waktu dan banyak klik ini dinilai cukup baik. Total tingkat keberhasilan pengguna adalah sebesar 260 task diselesaikan dari keseluruhan 300 task atau $87 \%$ task mampu diselesaikan pengguna. Banyak error yang dilakukan responden pembeli ada 108 error dari maksimum 300 kesalahan. Hal ini berarti tingkat error sebesar 0,36 yang berada dalam tingkat wajar.

\section{F. Hasil Uji Usabilitas Admin Pembeli}

Uji usabilitas admin pembeli dilakukan dengan lima responden dengan jumlah task sebanyak enam. Pengujian dilakukan dengan cara dan untuk variabel yang dama dengan pembeli dan penjual, yaitu time on task, number of click, task success dan banyak error. Hasil uji usabilitas penjual dapat dilihat pada Tabel V.

Tabel V memberikan informasi bahwa total waktu yang dibutuhkan pengguna untuk menyelesaikan semua task adalah 163 detik dengan rata-rata waktu 27,1 detik. Jika dibandingkan dengan data benchmark time on task pada Tabel III diketahui bahwa time on task rate untuk pembeli adalah 1,81 yang berarti pengguna membutuhkan waktu 2,06 kali dari tim pengembang. Sementara itu untuk number of clicks diketahui bahwa rerata total klik yang dibutuhan pengguna adalah $20 \mathrm{klik}$ atau sekitar 1,82 jika dibandingkan dengan jumlah minimum klik oleh tim pengembang yaitu sebesar 11 klik. Tingkat time on task utk admin pembeli dinilai kurang karena lebih dari 2 kali waktu benchmark yang ditentukan sedangkan dan banyak klik dinilai cukup baik. Total tingkat keberhasilan pengguna adalah sebesar 25 task diselesaikan dari keseluruhan 30 task atau 83\% task mampu diselesaikan pengguna. Banyak error yang dilakukan responden pembeli ada 13 error dari maksimum 30 error. Hal ini berarti tingkat error sebesar 0,43 yang berada dalam tingkat wajar.

\section{G. Hasil Uji Usabilitas Admin Penjual}

Uji usabilitas admin penjual dilakukan terhadap 5 responden dengan variable uji yang sama dengan pengguna lain yaitu time on task, number of click, task success dan banyak error. Hasil uji usabilitas penjual dapat dilihat pada Tabel VI. Total waktu yang 
dibutuhkan pengguna untuk menyelesaikan semua task adalah 432 detik dengan rata-rata waktu 27 detik. Jika dibandingkan dengan data benchmark time on task pada Table III diketahui bahwa time on task rate untuk pembeli adalah 1,81 yang berarti pengguna membutuhkan waktu 1,92 kali dari tim pengembang. Sementara itu untuk number of clicks diketahui bahwa rerata total klik yang dibutuhan pengguna adalah $29 \mathrm{klik}$ atau sekitar 1,78 jika dibandingkan dengan jumlah minimum klik oleh tim pengembang yaitu sebesar 46 klik. Waktu dan banyak klik ini dinilai cukup baik. Total tingkat keberhasilan pengguna adalah sebesar 63 task diselesaikan dari keseluruhan 80 task atau $83 \%$ task mampu diselesaikan pengguna. Banyak error yang dilakukan responden pembeli ada 29 error dari maksimum 80 error. Hal ini berarti tingkat error sebesar 0,41 yang berada dalam tingkat wajar.

\section{H. Rangkuman Hasil Uji Usabilitas}

Analisis keseluruhan hasil uji usabilitas terhadap sistem pembelian dan penjualan produk pertanian secara online dilakukan dengan menghitung time on task rate, Number of Clicks Rate, Task Success Rate dan Error Rate. Perumusan tingkat usabilitas semua variabel dihitung menggunakan rumus 1 sampai 4 , sebagai acuan nilai setiap variable yang dibutuhkan pada rumus dapat dilihat pada Tabel VII. Hasil perhitungan tingkat usabilitas sistem dikelompokan menjadi variable efisiensi dan efektifitas sistem. Variabel efisiensi diukur melalui nilai Time on Task Rate dan Number of Clicks Rate, sedangkan variabel efektifitas diukur melalui Task
Success Rate dan Error Rate. Rangkuman hasil uji usabilitas sistem dapat dilihat pada Tabel VIII.

Informasi pada Tabel VIII menampilkan hasil keseluruhan uji usabilitas sistem pembelian dan penjualan. Data menunjukan bahwa rata-rata Time on Task Rate dan Number of Clicks Rate adalah 1,88 dan 1,77 yang berarti efisiensi sistem cukup. Hal ini didasarkan pada nilai kedua variabel kurang dari 2 namun melebihi 1,5 [17]. Untuk efektifitas sistem didapat hasil sistem memiliki efektifitas yang baik dengan Task Success Rate sebesar 0,83 dan Error Rate yang wajar yaitu sebesar 0,41 [8]. Meskipun secara keseluruhan hasil uji usabilitas menunjukan hasil baik dan cukup namun masih banyak kekurangan yang terdapat pada sistem.

TABEL $\mathrm{V}$

HASIL UJI USABILITAS ADMIN PEMBELI

\begin{tabular}{lcc}
\hline \multicolumn{1}{c}{ Variabel } & Total & Rerata \\
\hline Time on Task $($ detik) & 163 & 27,1 \\
Number of Clicks & 20 & - \\
Number of Task Success & 25 & 5 \\
Number of Error & 13 & 2,17 \\
\hline
\end{tabular}

TABEL VI

HASIL UJI USABILITAS ADMIN PENJUAL

\begin{tabular}{lcc}
\hline \multicolumn{1}{c}{ Variabel } & Total & Rerata \\
\hline Time on Task $($ detik) & 432 & 27 \\
Number of Clicks & 82 & - \\
Number of Task Success & 63 & 3,94 \\
Number of Error & 29 & 1,81 \\
\hline
\end{tabular}

TABEL VII

NILAI ACUAN VARIABEL UNTUK MENGHITUNG TINGKAT USABILITAS

\begin{tabular}{lcccc}
\hline Variabel & Pembeli & Penjual & Admin Pembeli & Admin Penjual \\
\hline Total waktu benchmark & 432 & 561 & 79 & 225 \\
Total minimal click benchmark & 81 & 112 & 11 & 46 \\
Jumlah responden & 30 & 30 & 5 & 5 \\
Jumlah task & 7 & 10 & 6 & 16 \\
Total seluruh task & 210 & 300 & 30 & 80 \\
Total Maksimum error & 210 & 300 & 30 & 80 \\
\hline
\end{tabular}

TABEL VIII

TINGKAT USABILITAS KESELURUHAN SISTEM

\begin{tabular}{llcccccc}
\hline \multirow{2}{*}{$\begin{array}{l}\text { Variabel } \\
\text { Usabilitas }\end{array}$} & Variabel Uji & Pembeli & Penjual & $\begin{array}{c}\text { Admin } \\
\text { Pembeli }\end{array}$ & $\begin{array}{c}\text { Admin } \\
\text { Penjual }\end{array}$ & $\begin{array}{c}\text { Rata-rata } \\
\text { nilai }\end{array}$ & $\begin{array}{c}\text { Nilai } \\
\text { Kualitas }\end{array}$ \\
\cline { 3 - 6 } Efisiensi & Time on Task Rate & 1,81 & 1,73 & 2,06 & 1,92 & 1,88 & Cukup \\
& Number of Click & 1,63 & 1,86 & 1,82 & 1,78 & 1,77 & Cukup \\
& Rate & 0,84 & 0,87 & 0,83 & 0,79 & 0,83 & Baik \\
Efektifitas & Task Success Rate & 0,49 & 0,36 & 0,43 & 0,36 & 0,41 & Wajar \\
& Error Rate & & & & & &
\end{tabular}




\section{PENUTUP}

Melalui uji usabilitas terhadap sistem pembelian dan penjualan yang dikembangkan didapat hasil bahwa tingkat efisiensi dan efektifitas sistem dinilai cukup dan baik. Oleh karena itu perlu dilakukan perbaikan terhadap sistem untuk meningkatkan efisiensi dari sistem.

\section{UCAPAN TERIMA KASIH}

Terima kasih disampaikan kepada Lembaga Penelitian dan Pengabdian Universitas Kristen Duta Wacana dan Fakultas Teknologi Informasi yang telah menyediakan fasilitas dan pendanaan untuk pelaksanaan penelitian dan penerbitan artikel ini.

\section{DAFTAR PUSTAKA}

[1] R. DELIMA, H. B. SANTOSO and J. PURWADI, "Kajian Aplikasi Pertanian yang Dikembangkan di Beberapa Negara Asia dan Afrika," in Seminar Nasional Aplikasi Teknologi Informasi, Yogyakarta, 2016.

[2] H. B. SANTOSO and R. DELIMA, "Stakeholder Definition for Indonesian Integrated Agriculture Information System (IAIS)," in The International Conference on Information Technology and Digital Applications, Yogyakarta, 2016.

[3] H. B. SANTOSO, C. MALVIN and R. DELIMA, "Pengembangan Sistem Informasi Pendataan Petani dan Kelompok Tani," in Seminar Nasional Sistem Informasi Indonesia, Sanur, 2017.

[4] R. DELIMA, H. B. SANTOSO, N. ANDRIYANTO and A. WIBOWO, "Development of Purchasing Module for Agriculture e-Commerce using Dynamic System Development Model," International Journal of Advanced Computer Science and Applications, vol. 9, no. 10, pp. 86 - 96, 2018.

[5] INTERNATIONAL STANDARD ORGANIZATION, "Ergonomics of human-system interaction - Part 11: Usability: Definitions and concepts," 2018. [Online]. Available: https://www.iso.org/obp/ui/\#iso:std:iso:9241:-11:ed2:v1:en. [Accessed 20 November 2019].

[6] J. NIELSEN, "How Many Test Users in a Usability Study?," 2012. [Online]. Available: https://www.nngroup.com/articles/how-many-testusers/. [Accessed 12 November 2019].
[7] D. S. Wibowo, "Usability Testing Sistem pada EAcademic Politeknik Harapan Bangsa," Emitor, vol. Vol. 16, no. No. 01, pp. 16-22, 2016.

[8] J. SAURO, "10 Benchmarks For User Experience Metrics,” 2012. [Online]. Available: https://measuringu.com/ux-benchmarks/. [Accessed 20 October 2019].

[9] N. P. L. SANTIARI and I. G. S. RAHAYUDA, "Analisis Kualitas Website Alumni STIKOM BALI Menggunakan Metode webqual," Jurnal Teknologi Informasi dan Ilmu Komputer, vol. 5, no. 2, pp. 231-238, 2018.

[10] WARJIYONO and C. M. HELLYANA, "Pengukuran Kualitas Website Pemerintah Desa Jagalempeni Menggunakan Metode Webqual 4.0," Jurnal Teknologi Informasi dan Ilmu Komputer, vol. 5, no. 2, pp. 139-146, 2018.

[11] B. AULIA, C. SAPUTRA and A. PINANDITO, "Analisis Usability Pada Website Universitas Brawijaya Dengan Heuristic Evaluation," Jurnal Teknologi Informasi dan Ilmu Komputer, vol. 3, no. 3, pp. 188 193, 2016.

[12] M. Išoraitė and N. Miniotienè, "Electronic Commerce : Theory and Practice," Integrated Journal of Business and Economics (IJBE), vol. Volume 2, no. Issue 2, pp. 73-79, 2018.

[13] E. TURBAN, D. KING, J. LEE, T.-P. LIANG and D. TURBAN, Electronic Commerce: A Managerial and Social Networks Perspective, 7th Edition ed., Pearson, 2012.

[14] G. P. JATI, "Transaksi e-Commerce Indonesia Capai US\$ 10 Miliar," 2014. [Online]. Available: http://www.cnnindonesia.com/ekonomi/201409231424 23-92-4073/transaksi-e-commerce-indonesia-capai-us-10-miliar. [Accessed 20 November 2019].

[15] A. G. KHAN, "Electronic Commerce: A Study on Benefits and Challenges in an Emerging Economy," Global Journal of Management and Business Research (B), vol. XVI, no. I, pp. 19-22, 2016.

[16] J. Sauro and J. R. Lewis, Quantifying the User Experience : Practical Statistics for User Research, United States: Elsevier, 2016.

[17] J. SAURO, "10 Things to Know about Task Times," Measuring U, 9 August 2011. [Online]. Available: https://measuringu.com/task-times/. [Accessed 1 April 2020]. 
JUITA: Jurnal Informatika e-ISSN: 2579-8901; Volume 8, Nomor 2, November 2020 